\title{
The effect of promotion on sales at PT. 3M Indonesia Surabaya Branch
}

\author{
Akhmad Nasir', Damarsari Ratnasahara Elisabeth ${ }^{2}$, Joko Suyono ${ }^{3,}$ Rurit Irma Ifadah ${ }^{4}$ \\ ${ }^{1}$ Sekolah Tinggi Ilmu Ekonomi Gempol, Management Department, Gempol Pasuruan, Indonesia. \\ ${ }^{2}$ Sekolah Tinggi Ilmu Ekonomi Mahardhika, Management Department, Surabaya, Indonesia. \\ ${ }^{3}$ Universitas Narotama, Department of Management and Business, Surabaya, Indonesia. \\ ${ }^{4}$ Sekolah Tinggi Ilmu Ekonomi Gempol, Management Department, Gempol Pasuruan, Indonesia.
}

nasirgempol@gmail.com

\begin{abstract}
The purpose of this study is to determine the effect of promotion on sales at PT. 3M Indonesia Surabaya Branch. The sample used in this study amounted to 30 consumers. The analysis technique used is simple linear regression analysis and simple determination. In order to test the effect of partial and simultaneous of these independent variables, the researcher conducted a partial test ( $\mathrm{t}$ test) and simultaneous test $(\mathrm{F}$ test). The variables used are sales (Y) and promotion (X) and data analysis tool using simple regression formula, correlation coefficient and determination. The results of the study show that the regression equation is $\mathrm{Y}=17,020+0,320(\mathrm{x})$ with $\mathrm{Y}$ value of 17,020 which means that if the promotion $(\mathrm{X})$ value is 0 , then sales $(\mathrm{Y})$ is 17,020 . And the promotion variable regression coefficient $(\mathrm{X})$ is 0.320 . This means that if promotion $(\mathrm{X})$ increases by 1 unit, then an increase in sales (Y) will increase by 0.320 . Based on the results of the correlation coefficient test shows a positive value, meaning that Ho is rejected and $\mathrm{Ha}$ is accepted, it can be concluded that there is a significant effect between promotion and sales at PT. $3 \mathrm{M}$ Indonesia Surabaya Branch.
\end{abstract}

Keywords: promotion, sales

\section{INTRODUCTION}

Companies in the global era are now increasingly advanced and rapidly developing, encouraging a company to increase its activities in conducting sales promotions. This arises because of the increasingly widespread market competition in the current era. To deal with market competition the company must focus on sales promotion activities that are expected to increase sales and have a good influence on company profits for the short and long term. Companies engaged in trade, sales promotion is something that is not possible to be ignored, because there is no trading company that does not carry out sales promotions in carrying out all forms of product sales activities. Sales promotion is done in a variety of good ways through print media and electronic media, both those that use large budget and even the smallest. Sales promotion has held the most important role in achieving the goals of a trading business or business that is engaged in selling products. All activities of the sale are sure to have a goal in generating a large sales improvement and must be profitable, but without the support of a good sales promotion, the

The effect of promotion on sales at PT. 3M Indonesia Surabaya Branch

Akhmad Nasir ${ }^{1,}$ Damarsari Ratnasahara Elisabeth ${ }^{2}$, Joko Suyono ${ }^{3,}$ Rurit Irma Ifadah ${ }^{4}$ 
sales improvement is not necessarily able to be optimal. Promotion is an important factor in realizing the company's goal of increasing sales.

With promotion consumers will increasingly know the advantages of the products that are owned by the company. Swasta and Irawan (2005:349) states that promotion is essentially a form of marketing communication that aims to encourage demand, which is meant by marketing communication is a marketing activity that seeks to disseminate information, influence and or remind the target market of the company and in its products to be willing to accept, buy, and loyal to the product or service offered by the company concerned. So promotion is one of the important aspects in marketing management because promotion can make consumers who are initially less interested in a product can change their mind to be interested in the product.

Promotion as one of the important marketing mix coverage in marketing goods or services produced by the company and also as a way of providing information to the public about the goods or services produced by the company. Promotion is a form of marketing communication, namely marketing activities that attempt to disseminate information, influence, persuade and or remind the target market of the company and its products so that consumers are willing to accept, buy, and loyal to the products offered by the company, Tjiptono (2002:148) expalin that communication between companies and consumers through promotional programs is important because promotion also determines the success of a marketing program. Saladin (2003: 21) suggests that the implementation of promotional activities carried out by companies can be through four types of tools, namely: advertising, personal selling, publicity and sales promotion.

Production results can be known by prospective consumers or the public if the company is able to introduce its products to the public or prospective consumers. Various ways to introduce products to prospective customers, one of which is by way of promotion or advertising. In this promotional or advertising activity, it is expected that prospective customers can find out about or the benefits of a product, so that in deciding the choice of consumers they do not experience mistakes and can feel the superiority of one product as desired by consumers. If in conducting promotional activities one company is less effective, both in the form of place, frequency, and time, then the possibility of achieving the company's goals increases sales is not achieved so that it will disrupt the continuity of the company.

Sales improvement is one of the most important factors that cannot be ignored. The success of a business is largely determined by how many products are sold. The greater the sales the higher the profit gained. There are several strategies that must be implemented and the strategy will certainly not give results in a very short time. The important role of marketing to realize the success of a business is by planning a marketing plan strategy that are correct in covering the Product, Place, Price, Promotion. Increasing sales is a big challenge for businesses because the success or failure of a business is largely determined by how many products sell on the market. The following are strategies in increasing sales, namely as follows:

a) Target potential market

b) Promotion

c) Attractive offers

d) Bonus for each purchase

e) Product development

The existence of very tight competition in the world of industry and marketing today, companies must determine the right strategy so that it can achieve the expected results. In this case PT 3M Indonesia to sell its products through various kinds of promotions including brochures, installing banners, shop signs, branding, making attractive displays, making direct sales at an event, and giving discounts. In order to reach the goal in the form of a larger and profitable sales, then the right and proper sales promotion must be done immediately, because basically sales promotion has an important goal which will further support the achievement of a more optimal sales and certainly very profitable for the company.

The effect of promotion on sales at PT. 3M Indonesia Surabaya Branch

Akhmad Nasir ${ }^{1}$, Damarsari Ratnasahara Elisabeth ${ }^{2}$, Joko Suyono ${ }^{3}$, Rurit Irma Ifadah ${ }^{4}$ 
Table 1 : Promotion Activity PT. 3M Indonesia, Surabaya Branch

\begin{tabular}{|c|c|c|c|c|c|}
\hline Year & Advertising & Sales Promotion & Personal Selling & Publicity & Total \\
\hline 2011 & 188 & 352 & 107 & 73 & 720 \\
\hline 2012 & 201 & 239 & 66 & 81 & 587 \\
\hline 2013 & 174 & 276 & 192 & 144 & 786 \\
\hline 2014 & 216 & 402 & 101 & 98 & 817 \\
\hline 2015 & 232 & 397 & 96 & 116 & 841 \\
\hline
\end{tabular}

Source: PT 3M Indonesia, Surabaya Branch

\section{Formulation of the Problem}

In accordance with the background of the problem above, the formulation of the problem can be as follows:

1. Does promotion have a simultaneous effect on the sales of PT 3M Indonesia Surabaya branch?

2. Does promotion have a partial effect on the sales of PT 3M Indonesia Surabaya branch?

\section{LITERATURE REVIEW AND HYPOTHESES}

\section{Marketing Mix}

In marketing there is a marketing strategy called the marketing mix that has an important role in influencing consumers to be able to buy a product or service offered by the company. The marketing mix elements consist of all variables that can be controlled by the company to be able to satisfy the consumers. The success of a company in achieving its stated goals depends on the composition of the marketing strategy in the company. Every company uses a number of tools to get consumer responses to marketing activities carried out by the company. One of the tools used by companies in compiling a marketing strategy is by using the marketing mix.

Marketing mix is a series of marketing tools that can be controlled, which include products, prices, places, and promotions that can be integrated by the company to produce the desired response by the company in achieving market targets (Kotler and Armstrong, 2008:272). While according to Anoraga (2000: 220), the marketing mix variables that can be controlled by the company consisting of products, prices, distribution and promotion. Marketing mix is marketing variables that can be modified and controlled by the company to attract consumers in choosing products and increasing sales turnover.

Marketing mix is marketing variables that can be arranged in such a way that can increase company sales. Marketing mix concept according to Kotler and Keller (2012:25) consists of 4P, namely product, price, place, and promotion. The understanding of each marketing mix is as follows:

1) Product

2) Price

3) Place

4) Promotion

Based on the description above it can be concluded that marketing mix is marketing elements that are interrelated, mixed, organized and used appropriately, so that the company can achieve effective marketing goals, while satisfying the needs and desires of consumers.

The effect of promotion on sales at PT. 3M Indonesia Surabaya Branch

Akhmad Nasir ${ }^{1,}$ Damarsari Ratnasahara Elisabeth ${ }^{2}$, Joko Suyono ${ }^{3,}$ Rurit Irma Ifadah ${ }^{4}$ 


\section{Promotion}

Kottler (2002:41) suggests that "Promotion is a variety of activities carried out by companies that highlight the features of their products that persuade target consumers to buy them". While Swasta and Irawan (2005: 349) argue that promotion is essentially a form of marketing communication that aims to encourage demand, which is meant by marketing communication is a marketing activity that seeks to disseminate information, influence and or increase the target market for the company and for its products to be willing to accept, buy and be loyal to the product or service offered by the company concerned. Tjiptono (2001:219) defines promotion is essentially a marketing communication, meaning marketing activities that try to disseminate information, influence or persuade, and or remind the target market of the company and its products to be willing to accept, buy and be loyal to the products offered by the company concerned.

The purpose of sales promotions is very diverse, namely stimulating demand, increasing consumer desire to try products, forming goodwill, increasing consumer purchases, can also encourage consumers to buy more and minimize brand-changing behavior, or encourage consumers to try purchasing new products. Nickels, et al (2008:10) suggested that promotion aims to influence the community to participate in purchases. Promotion also aims to motivate people to buy products or services of a company and can be a means to build relationships with customers. The main purpose of promotion in principle is to modify consumer behavior, inform, influence and persuade and remind consumers about the company's goals and products and services that they sell Swast \& Irawan (2005:353) which in detail can be described as follows:

1. Modify the behavior of prospective customers

2. Providing information

3. Persuade and influence

4. Remind consumers and give an impression on one product.

5. Satisfying desire

6. As a communication tool

The factors that influence promotion according to Basu Swastha (2003: 240-245) are as follows:

1. Funds used for Promotion

2. Nature of the Market

3. Product Type

4. Stages of the Goods Life Cycle

\section{Sales}

Kottler (2003:17) sales are interactions between individuals meeting each other face aimed at creating, repairing, mastering or maintaining exchange relations that are beneficial to other parties. According to Winardi (2005:26) sales are a gathering of buyers and sellers with the aim of carrying out the exchange of goods and services based on valuable considerations such as consideration of money. "Sales according to Thamrin Abdullah and Francis Tantri (2016:3) sales are part of promotions and promotions is one part of the whole marketing system.

According to Kotler (2003:17) the types of sales are as folows:

\section{Trade Selling}

The effect of promotion on sales at PT. 3M Indonesia Surabaya Branch

\section{Akhmad Nasir ${ }^{1,}$ Damarsari Ratnasahara Elisabeth ${ }^{2}$, Joko Suyono ${ }^{3,}$ Rurit Irma Ifadah ${ }^{4}$}




\section{Missionary Selling \\ 3. Technical Selling \\ 4. New Business Selling \\ 5. Responsive Selling}

Factors affecting sales according to Winardi (2005:30) are as follows:

1. Seller Conditions and Capabilities

2. Market Conditions

3. Capital

4. Condition of company organization

5. Other factors

\section{Sales volume}

Arifinal Chaniago (1995:14) gives an opinion about sales volume is the total amount of income obtained from the sale of an item or service in a certain period of time. Whereas according to Basu Swastha (1983:14) provides an understanding of sales volume is an accumulation of sales activities of a product of goods and services that are calculated as a whole for a certain period of time continuously or in one accounting process.

The indicators of sales volume are as follows (Basu Swastha, 2005: 65)

1. Total Sales, is a net sales from the company's earnings report. Net sales are obtained through the sales of all products (line products) over a certain period of time and the results of sales achieved from the market share which is a potential sales that can consist of groups of buyers for a certain period of time.

2. Profit, is the income received by the company minus the company's operations in a particular operation. The operating profit/profit is net income which is a measure of success for a company.

Swasta (1999:121) defines factors that affect the size of the sales volume as follows:

1. Internal factors

a) The company's ability to manage products that will be marketed

b) Price and promotion policies outlined by the company.

c) Policy to choose the intermediary used.

\section{External factors}

a) Economic and trade developments both nationally and internationally, trade and monetary.

b) Government policies in the economic, trade and monetary fields.

c) Atmosphere of market competition.

\section{METHODS}

This study uses a type of descriptive research with a quantitative approach. Quantitative research methods, as stated by Sugiyono (2012:58) "Research methods that are based on the philosophy of positivism, are used to examine certain populations or samples, data collection using research instruments, quantitative/statistical data analysis, with the aim of testing predetermined hypothesis".

The effect of promotion on sales at PT. 3M Indonesia Surabaya Branch

\section{Akhmad Nasir ${ }^{1,}$ Damarsari Ratnasahara Elisabeth ${ }^{2}$, Joko Suyono ${ }^{3}$, Rurit Irma Ifadah ${ }^{4}$}


Population and Sample

According to Arikunto (2010:108) "population is the whole subject of research. If someone wants to examine all the elements in the research area, the research is population research." The population in this study were consumers of 3M Indonesia products, Surabaya branch office.

Sugiyono (2010: 116) says that the sample is "part of the number and characteristics possessed by the population". As for sample collection using the simple random sampling method, which is taking samples from the population randomly without regard to the strata in the population (Sugiyono, 2010:152). To determine the number of samples taken in this study the following formula is used (Yamane in Rachmat, 1985: 84):

$$
\mathrm{N}=\frac{N}{N d^{2}+1}
$$

diketahui :

$$
\begin{aligned}
& \mathrm{N}=42 \\
& \mathrm{~d}=10 \%(0,1) \\
& \mathrm{n}=\frac{42}{\left(42 \cdot 0,1^{2}+1\right)} \\
& \mathrm{n}=\frac{42}{(42 \cdot 0,01+1)} \\
& \mathrm{n}=\frac{42}{(0,42+1)} \\
& \mathrm{n}=\frac{42}{(1,42)}=29,58=30
\end{aligned}
$$

The number of samples used follows the rules of the Slovin Formula, namely the total population $(\mathrm{N}=$ 42) will produce a minimum number of samples of 30 respondents.

The instrument used is the Likert scale. According to Istijanto, (2006) the Likert scale measures the level of agreement or disagreement of respondents towards a series of statements of an object. In general, this scale has 5 categories from "strongly agree" to "strongly disagree". The way to measure it is to confront a respondent with a question and then be asked to give an answer:

- Answers strongly agree to be given a score of 5

- Answers agree to be given a score of 4

- Answers hesitant to be given a score of 3

- Answers do not agree to be given a score of 2

- Answers strongly disagree to be given a score of 1

\section{Data Analysis Techniques}

a. Simple regression analysis

The data analysis method of this study uses the SPSS program (statistical package for social science). Simple regression analysis is used to explain the relationship between the data on the dependent variable

The effect of promotion on sales at PT. 3M Indonesia Surabaya Branch

\section{Akhmad Nasir', Damarsari Ratnasahara Elisabeth ${ }^{2}$, Joko Suyono ${ }^{3}$, Rurit Irma Ifadah ${ }^{4}$}


and the independent variable, it is necessary to determine the analytical method to be used, because in this study using 1 (one) variable, the analysis method used is a simple regression with the following equation:

$\mathrm{Y}=\mathrm{a}+\mathrm{bX}+\mathrm{e}$

(Sugiyono, 2009: 204)

Where :

Y: Dependent variable (promotion)

a: Number of regression constants for $\mathrm{X}=0$

b: Independent variable regression coefficient

$\mathrm{X}$ : Independent Variables (Sales)

Where the values of $a$ and $b$ can be searched by the formula as follows(Sugiyono, 2009: 204):

$$
\begin{aligned}
\mathrm{a} & =\frac{\left(\sum x_{i}\right)\left(\sum x_{i}^{2}\right)-\left(\sum x i\right)\left(\sum x_{i} \sum y_{i}\right)}{n\left(\sum x_{i}^{2}\right)-\left(\sum x_{i}\right) 2} \\
\mathrm{~b} & =\frac{\left(\sum x_{i} \sum y_{i}\right)-\left(\sum x_{i} y_{i}\right)}{n\left(\sum x_{i}^{2}\right)-\left(\sum x_{i}\right) 2}
\end{aligned}
$$

b. Classic assumption test

The classic assumption test is carried out to determine whether or not there is a classic assumption deviation. The use of analytical methods in regression in hypothesis testing is first tested whether the model has met the classic assumptions or not. Testing assumptions consist of tests of normality, linearity and homogeneity.

\section{RESULT AND DISCUSSION}

1. Simple Linear Regression Analysis:

Table 2 : Coefficients

Coefficients $^{\mathrm{a}}$

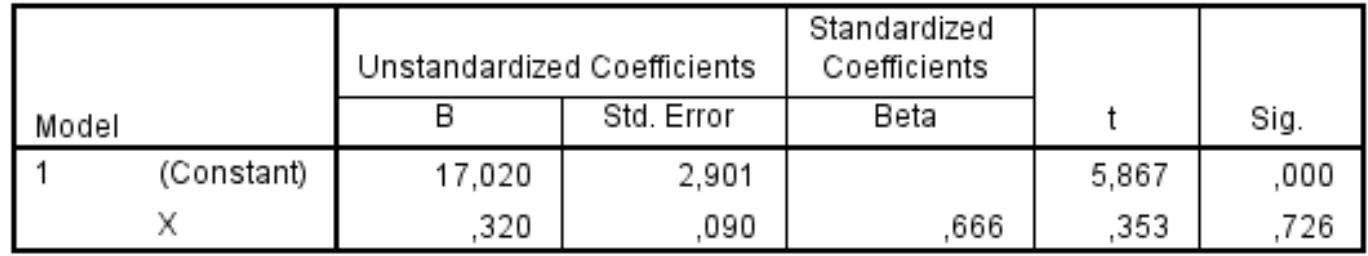

a. Dependent Variable: $Y$

Based on the table above, the regression equation is obtained as follows:

$\mathrm{Y}=17,020+0.320 \mathrm{X}$

This means that if the promotion increases by 1 unit, then work productivity will increase by 0.320 .

2. Classic assumption test

The effect of promotion on sales at PT. 3M Indonesia Surabaya Branch

Akhmad Nasir ${ }^{1,}$ Damarsari Ratnasahara Elisabeth ${ }^{2}$, Joko Suyono ${ }^{3,}$ Rurit Irma Ifadah ${ }^{4}$ 
a. Normality test

Classical assumption testing in this study uses normality testing. If the testing of the classical assumption is not violated, then testing with a hypothesis based on linear regression analysis will be considered valid.

Normality testing is done on residual regression. One assumption in the use of regression models is that data is normally distributed or residuals spread around zero. The normality test in this study was carried out by the Kolmogorov-Smirnov method. If the residual value spreads normally then the regression equation obtained is good enough with the criteria of a significant value greater than $\alpha=0.05$.

Table 3 : Kolmogorov Smirnov

One-Sample Kolmogorov-Smirnov Test

\begin{tabular}{|c|c|c|c|}
\hline & & $\bar{x}$ & $\mathrm{Y}$ \\
\hline N & & 30 & 30 \\
\hline \multirow[t]{2}{*}{ Normal Parameters ${ }^{a, b}$} & Mean & 31,9000 & 16,0000 \\
\hline & Std. Deviation & 3,28371 & 1,57568 \\
\hline \multirow[t]{3}{*}{ Most Extreme Differences } & Absolute & 141 & , 171 \\
\hline & Positive &, 141 & , 171 \\
\hline & Negative &,- 092 &,- 129 \\
\hline Test Statistic & &, 141 & ,171 \\
\hline Asymp. Sig. (2-tailed) & & $130^{\circ}$ &, $026^{\mathrm{c}}$ \\
\hline
\end{tabular}

a. Test distribution is Normal.

b. Calculated from data.

c. Lilliefors Significance Correction.

Based on the table of results of the normality test using the Kolmogorov-Smirnov test, a significance value of 0.130 is obtained. This value is greater than the significance of 0.05 so it can be concluded that the data tested is normally distributed.

In the normal PP Plot graph, normal data is data that forms points that spread not far from the diagonal line. The results of linear regression analysis with normal P-P Plot graphs against the residual error of the regression model have been shown to show a normal graph pattern, namely the distribution point that is not far from the diagonal line.

The effect of promotion on sales at PT. 3M Indonesia Surabaya Branch 


\section{Normal P-P Plot of Regression Standadized Residual}

Dependent Variable: Sales

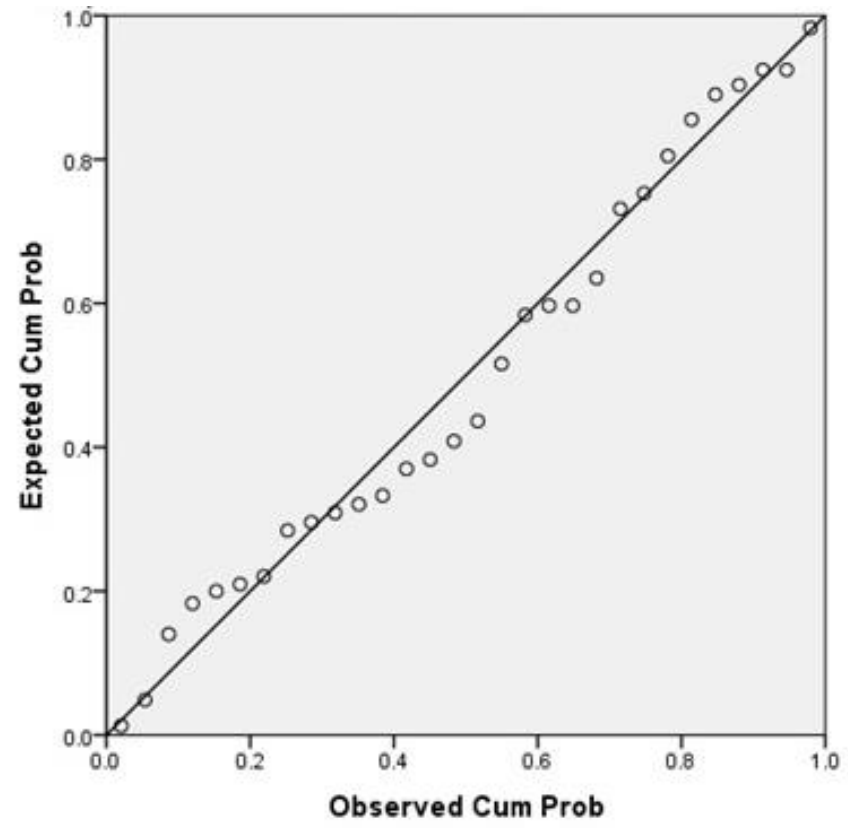

Figure 1 : P-P Plot

b. Linearity Test

Linearity test is conducted to find out whether the two variables have a linear or not significant relationship. The rule used to test data linearity is:

If the significance (significance level) $>0.05$ then it does not have a linear relationship.

If the significance (significance level) $<0.05$ then the data has a linear relationship.

Table 4 : Anova

\begin{tabular}{|c|c|c|c|c|c|c|c|}
\hline & & & $\begin{array}{l}\text { Sum of } \\
\text { Squares }\end{array}$ & $\mathrm{df}$ & $\begin{array}{l}\text { Mean } \\
\text { Square }\end{array}$ & $\mathrm{F}$ & Sig \\
\hline \multirow{6}{*}{$\begin{array}{l}\text { Sales } \\
\text { Promotion } \\
\text { from linearity }\end{array}$} & Between Groups & (Combined) & 33.976 & \multirow{4}{*}{$\begin{array}{ll} & 1 \\
3 & \\
& 1 \\
& 1 \\
& 2\end{array}$} & 2.614 & 1.100 & .422 \\
\hline & & Linearity & .320 & & .320 & .135 & .719 \\
\hline & & Deviation & 33.656 & & 2.805 & 1.180 & .037 \\
\hline & \multicolumn{2}{|l|}{ Within Groups } & & & & & \\
\hline & & 38.024 & $\begin{array}{l}1 \\
6\end{array}$ & 2.376 & & \\
\hline & & & 72.000 & $\begin{array}{l}2 \\
9\end{array}$ & & & \\
\hline
\end{tabular}

The effect of promotion on sales at PT. $3 M$ Indonesia Surabaya Branch

\section{Akhmad Nasir $^{1,}$ Damarsari Ratnasahara Elisabeth ${ }^{2}$, Joko Suyono ${ }^{3,}$ Rurit Irma Ifadah ${ }^{4}$}


Based on the results of the linearity test table, obtained a significance value of 0.037 . This value is smaller than the significance of 0.05 so that it can be concluded that the data tested is linear.

\section{c. Homogeneity Test}

Homogeneity testing is a test of whether or not the variances are equal to two or more distributions. The homogeneity test was carried out to find out whether the data in variables X and Y were homogeneous or not. This test was carried out as a requirement in the independent analysis of t-test and ANNOVA samples. The underlying assumption in the analysis of variance is that the variants of the population are the same. As a testing criterion, if the significance is more than 0.05 then it can be said that the variant of two or more groups of data is the same.

Table 5 : Anova ${ }^{a}$

Sales

\begin{tabular}{|l|r|r|r|r|r|}
\hline & $\begin{array}{c}\text { Sum of } \\
\text { Squares }\end{array}$ & df & Mean Square & F & Sig. \\
\hline Between Groups & 33,976 & 13 & 2,614 & 1,100 &, 422 \\
Within Groups & 38,024 & 16 & 2,376 & & \\
Total & 72,000 & 29 & & & \\
\hline
\end{tabular}

Based on the Homogeneity test results table, obtained a significance value of 0.422 . This value is greater than the significance of 0.05 so it can be concluded that the data tested are homogeneous.

\section{3. t-Test Results}

Table 6 : Coefficients

Coefficients ${ }^{a}$

\begin{tabular}{|c|c|c|c|c|c|c|}
\hline \multirow{2}{*}{\multicolumn{2}{|c|}{ Model }} & \multicolumn{2}{|c|}{ Unstandardized Coefficients } & \multirow{2}{*}{$\begin{array}{c}\begin{array}{c}\text { Standardized } \\
\text { Coefficients }\end{array} \\
\text { Beta }\end{array}$} & \multirow[b]{2}{*}{$\mathrm{t}$} & \multirow[b]{2}{*}{ Sig. } \\
\hline & & $\mathrm{B}$ & Std. Error & & & \\
\hline \multirow[t]{2}{*}{1} & (Constant) & 17,020 & 2,901 & & 5,867 &, 000 \\
\hline & $\mathrm{X}$ &, 320 &, 090 &, 666 & 2,353 &, 026 \\
\hline
\end{tabular}

a. Dependent Variable: $Y$

Based on the table above, it can be explained the results of the Promotion variable t-test. The test results obtained by the value of $t$ for the promotion variable shows the value $t=2.353$ with a significance value of 0.026 . With a significance value below $0.05(0.026<0.05)$, indicating that the promotion variable has a significant effect on Sales. 
Table 7 : Anova ${ }^{a}$

\begin{tabular}{|c|c|c|c|c|c|c|}
\hline & & $\begin{array}{l}\text { Sum of } \\
\text { Squares }\end{array}$ & df & Mean Square & $\mathrm{F}$ & Sig. \\
\hline \multirow[t]{3}{*}{1} & Regression & 5,320 & 1 & \multirow{3}{*}{$\begin{array}{r}5,320 \\
12,560\end{array}$} & \multirow[t]{3}{*}{20,125} & \multirow[t]{3}{*}{, $000^{b}$} \\
\hline & Residual & 71,680 & 28 & & & \\
\hline & Total & 77,000 & 29 & & & \\
\hline
\end{tabular}

a. Dependent Variable: $Y$

b. Predictors: (Constant), $X$

From the output, it can be seen that $\mathrm{F}$ count is 20,125 with a significance of 0,000 . This shows that there is a real effect of the promotion on sales. The effect is significant considering the significance obtained is 0,000 . Significant value of $0,000<0,05$ indicates the effect of promotion variable has a significant effect on sales.

5. Analysis of Correlation (R) and Determination Coefficient $\left(\mathrm{R}^{2}\right)$

Table 8 : Model Summary ${ }^{b}$

\begin{tabular}{|l|c|r|r|r|}
\hline Model & $\mathrm{R}$ & $\mathrm{R}$ Square & \multicolumn{1}{c|}{$\begin{array}{c}\text { Adjusted R } \\
\text { Square }\end{array}$} & $\begin{array}{c}\text { Std. Error of } \\
\text { the Estimate }\end{array}$ \\
\hline 1 &, $667^{\text {a }}$ &, 604 &, 531 & 2,06000 \\
\hline
\end{tabular}

a. Predictors: (Constant), $X$

b. Dependent Variable: $Y$

Based on the table above, it is known that the $\mathrm{R}$ value is 0.667 . This shows that the relationship between the independent variable and the dependent variable is strong. The $\mathrm{R}^{2}$ value indicates the determination coefficient of 0.604 . While adjusted $R$ Square is 0.531 . The value of $R$ Square $\left(R^{2}\right)$ shows that the role of independent variables in influencing the dependent variable is $60.4 \%$. While the rest, which is $39.6 \%$ (from $100 \%-60.4 \%$ ) is influenced by other variables outside of this study.

Conclusion

Based on the results of the analysis and discussion previously stated, conclusions can be taken as follows:

1. Promotion have a simultaneous effect on the sales of PT 3M Indonesia Surabaya branch This can be seen from $F$ value where $F$ count is 20,125 with a significance of 0,000 . This shows that there is a real effect of the promotion on sales significant value of $0,000<0,05$, this indicates the effect of promotion variable has a significant effect on sales.

2. Promotion have a partial effect on the sales of PT 3M Indonesia Surabaya branch

This can be seen from $t$ value where $t$ value shows the value $t=2.353$ with a significance value of 0.026 . With a significance value below $0.05(0.026<0.05)$, indicating that the promotion variable has a significant effect on Sales. 


\section{REFERENCES}

Anoraga, P., (2008). Manajemen Bisnis, Jakarta: PT. Rineka Cipta.

Arikunto. Suharsimi, (2002). Prosedur Penelitian . Semarang : Rineka Cipta.

Arikunto, Suharsimi, (2010). Prosedur Penelitian Suatu Pendekatan Praktik, Jakarta : PT. Rineka Cipta.

Arifinal Chaniago, et al., (1995). Ekonomi 2, Bandung : Angkasa.

Assauri, Sofyan, (2009). Manajemen Pemasaran, Jakarta : Penerbit PT. Raja Grafindo Persada.

Hasan , I,. (2002), Pokok - Pokok Materi Metodologi Penelitian \& Aplikasinya, Jakarta: Ghalia Indonesia.

Indiartono and Supomo, (2002). Metedologi dan Penelitian Bisnis. Yogyakarta : BDFE

Kotler P., Armstrong G., Saunders J. Wong V., (2002). Principle of Marketing, 3rd edition, Prentice Hall Europe.

Kotler, P. and Keller, K. L., (2009). Marketing management (13th end). New Jersey: Pearson Education Inc, Upper Saddle River,

Kotler, (2000). Marketing Management, Millenium Edition, New Jersey : Prentice Hall.

Kotler dan Amstrong, (2008). Prinsip - Prinsip Manajemen Pemasaran. Edisi 12, Jilid I, Jakarta : Erlangga.

Kotler, Philip and Amstrong, Gery, (2008). Dasar-Dasar Pemasaran, Jakarta : Penerbit Pellindo.

Kotler, Philip and Kevin Lanne Keller, (2009). Manajemen Pemasaran Edisi 12 Jilid I, PT. Indeks, indeks@cbn.net,id- PT. Macana Jaya Cemerlang.

Kotler and Keller, (2012). Manajemen Pemasaran Edisi12, Jakarta : Erlangga.

Lamb, Hair and Mc.Daniel, (2001). Pemasaran Buku I. Jakarta : Salemba Empat.

Lupiyoadi and A. Hamdani, (2006). Manajemen Pemasaran Jasa. Edisi kedua. Jakarta, Salemba Empat.

Moekijat, (2000). Kamus Manajemen, Bandung : Penerbit CV. Mandar Maju.

McDaniel, (2001). Pemasaran, Edisi Pertama. Jakarta : Salemba Empat.

Nitisesmito and Alex.S, (2000). Marketing. Jakarta : PenerbitGhalia Indonesia.

Parasuraman, A., Zeithaml, V. A., \& Berry, L. L. (1988). SERVQUAL: A multiple-item scale for measuring consumer perceptions of service quality. Journal of Retailing, 64 (1), 12-40.

Ridwan, (2007). Skala Pengukuran Variabel-Variabel, Bandung : Alfabeta.

Saladin, (2003). Manajemen Pemasaran, Bandung : Linda Karya.

Sistaningrum, (2002). Manajemen Penjualan Produk, Yogyakarta : PT. Taristo.

Solomon, Micheal. R., (2009). Consumer behaviour, Buying, Having and Being, 8th edition, New York: Pearson education, inc.

Sugiyono, (2013). Metode Penelitian Kuantitatif, Kualitatifdan R\&D, Bandung : Alfabeta.

Sugiyono, (2015). Metode Penelitian Kombinasi (Mix Method), Bandung : Alfabeta.

Swastha, Basu, (2001). Manajemen Pemasaran Moderen, Yogyakarta : BDFE.

Swastha, Basu, (2003). Azas-Azas Marketing, Yogyakarta : Liberty.

Swastha, Basu and Irawan, (2005). Manajemen Pemasaran Moderen, Yogyakarta : Liberty.

Swastha, (2009). Manajemen Penjualan, Edisi ketiga, Yogyakarta : BPFE.

Swastha, Basu, (2002). Manajemen Pemasaran Edisi ketiga. Yogyakarta : BPFE.

Swasta, Basu and Sukotjo, (2002). Ilmu Pengantar Bisnis Moderen, Yogyakarta : Penerbit Liberty.

Swastha and Irawan, (2003). Manajemen Pemasaran Moderen, Yogyakarta : Liberty

Tjiptono, Fandy, (2002). Strategi Pemasaran Edisi kedua, Cetakan Keenam, Yogyakarta : Penerbit Andy.

Tjiptono, Fandy, (2004). Manajemen Pemasaran Jasa, Yogyakarta : Andi Offset.

Thamrin, Abdullah and Francis Tantri, (2016). Manajemen Pemasaran. Jakarta Depok : PT. Raja Grafindo Persada.

Zeithaml V. A., Bitner M. J., Gremler D. D., (2006). Services marketing, 4th edition, New York: McGraw-Hill 